with a rieh souree of phosphate of lime of organic origin, for manure, the remants of faunas of Secondary and Tertiary age, for the utilization of which we are indebted to the Rev. Prof. Henslow, and which may be referred to specially, as an instance of the practical applioation of Geology to the benefit of agriculture.

The relation of Geology to Agriculture forms, of itself, a most interesting chapter of this book; it is a subject of the greatest national importance, and we are glad to know that the Government Geological Surveyors are also becoming convinced that the superficial deposits are deserving of their attention and mapping.

The present book contains: Part I. "The Natural History of the Raw Materials of Commerce."-Part II. "The Commercial Products of the Vegetable Kingdom."-Part III. "The Commercial Products of the Animal Kingdom."-Part IV. "Raw Mineral Produce;" and, lastly, an Appendix, containing a Vocabulary of the Names of Natural Productions, in the Principal European and Oriental Languages. The Geographical Distribution of Food and Industrial Plants is illustrated by a small coloured map, showing the Botanical Zones of the world.

Dr. Yeats announces that the present volume will be followed by "The Industrial and Political History" and by "The Technical History" of the same subject.

Among the list of contributors to the present volume we observe the name of Mr. Ralph Tate, F.G.S., F.L.S., a good guarantee for the careful execution of the geological part of the volume.

We heartily wish the author and his book all possible good, and trust that the future volumes may turn out as agreeable and readable as the present one.

\title{
CORRESPOINDFITCF.
}

AVANTURLNE QUARTZ IN BRITAIN.

Sre,-In the Grox. Mua. for Sept, p. 444, you announce that Mr. G. W. Traill has discovered "Avanturine Quartz" in Orkney, on the shores of Inganess Bay. It is spoken of as "a scarce variety of quartz," but it is really not a scarce mineral, nor is it a variety of quartz, but only ordinary quartz inelosing seales of mica. It is commonly met with in micaceous sandstones all over the world, and has no more right to a distinctive title than a quartz crystal containing any other foreign body entangled in its mass.

LoNDoN, 3rd Sept., 1870.

\section{ARCHDEACON PRATT ON THE INTERNAL FLUIDITY OF THE EARTH.}

Srr.-All Geologists must rejoice to see a question of such interest as that of the Internal Fluidity of the Earth discussed in the pages of the Magazine by authorities like M. Delaunay and Archdeacon Pratt. I confess that M. Delaunay's arguments, as given to us by Mr. David Forbes, ${ }^{1}$ staggered my faith in Mr. Hopkins's

1 Geological Magazine, vol. v., p. 511. 